\title{
Production of High Viscosity Chitosan from Biologically Purified Chitin Isolated by Microbial Fermentation and Deproteinization
}

\author{
Ekkalak Ploydee and Saipin Chaiyanan \\ Department of Microbiology, Faculty of Science, King Mongkut's University of Technology Thonburi, Pracha Uthit Road, \\ Bangkok 10140, Thailand
}

Correspondence should be addressed to Saipin Chaiyanan; saipin.cha@kmutt.ac.th

Received 17 September 2013; Revised 16 December 2013; Accepted 8 March 2014; Published 23 April 2014

Academic Editor: Christopher Batich

Copyright (C) 2014 E. Ploydee and S. Chaiyanan. This is an open access article distributed under the Creative Commons Attribution License, which permits unrestricted use, distribution, and reproduction in any medium, provided the original work is properly cited.

\begin{abstract}
The objective of this study was to produce high viscosity chitosan from shrimp chitin prepared by using a two-step biological treatment process: decalcification and deproteinization. Glucose was fermented with Lactobacillus pentosus L7 to lactic acid. At a $\mathrm{pH}$ of $3.9 \pm 0.1$, the calcium carbonate of the shells was solubilized in 48 hours. The amounts of residual calcium in the form of ash $(1.4 \pm 0.5 \%)$ and crude protein $(23.2 \pm 2.5 \%)$ were further eliminated by the activity of proteolytic Bacillus thuringiensis SA. After decalcification and deproteinization of the shrimp shells, residual calcium and crude protein of shrimp chitin flakes were $1.7 \pm 0.4 \%$ and $3.8 \pm 1.3 \%$, respectively. Chitin was deacetylated with $50 \% \mathrm{NaOH}$ at $121^{\circ} \mathrm{C}$ for 5 hours. After deacetylation, the chitosan had residual calcium, crude protein content, and degree of acetylation of $1.6 \pm 0.6 \%, 0.4 \pm 0.3 \%$, and $83.2 \pm 1.5 \%$, respectively. The viscosity of chitosan prepared from chitin extracted by this two-step biological process was $1,007 \pm 14.7 \mathrm{mPa} \cdot \mathrm{s}$, whereas chitosan prepared from chemically processed chitin had a viscosity of $323 \pm 15.6 \mathrm{mPa} \cdot s$, indicating that biologically purified chitin gave chitosan with a high quality.
\end{abstract}

\section{Introduction}

The main unutilized biomass from the shrimp packaging and processing industries is heads and body carapaces, which constitute $45-50 \%$ of the wet weight of fresh shrimps [15]. About $20-40 \%$ of shrimp biowaste consists of chitin encrusted with calcium carbonate, protein, astaxanthin, and lipid residues [6,7]. Shrimp biowaste is often treated in landfills or discarded in sea water, resulting in ecological problems in coastal areas, whereas a small part is used as a major component in chicken or fish feed, mixed with other agricultural raw materials [6]. The exoskeletons of crustacean waste from the seafood industry are traditionally used to prepare commercial chitin and chitosan $[8,9]$. Chitin, or $\beta$ - $(1,4)$-linked $N$-acetyl glucosamine (GlcNAc), is the most abundant natural polysaccharide on earth after cellulose $[10$, $11]$. Chitin can be converted to chitosan $(\beta-(1,4)$-linked linear polymer of 2 -acetamide-2-deoxy- $\beta$-D-glucose) by deacetylation with concentrated $\mathrm{NaOH}$. Commercial applications of chitosan are influenced by its viscosity in solution. The viscosity of chitosan depends strongly on the viscosity of the "preproduct" chitin [6].

In commercial chitin extraction, chitin is usually isolated by a simple process which involves the use of alkaline and acid solutions to deproteinize and decalcify the shrimp shells; this is considered to be a non-environmentally friendly process. Chemical chitin extraction has a high efficiency for recovering purified chitin, but the process creates hazardous wastes which are harmful to human health and ecological systems $[6,7,12,13]$. In addition, the chemical process has a negative effect on the intrinsic and physical properties of purified chitin, leading to a decrease in the viscosity of chitosan [6]. Crude proteins and carotenoids in the extracting solution are useless after deproteinization and decalcification $[14,15]$. 
Continued chitin production by chemical processes without development and utilization of novel technologies cannot solve the problem of achieving environmental sustainability [15]. Currently, strictness in environmental protection has become a basic requirement for waste management in food and agricultural industries.

To overcome the shortcomings of chemical chitin purification, several biotechnological techniques have been developed that are considered to be efficient alternative approaches for recovery of high quality chitin $[4,6,15-18]$. The use of commercial crude enzymes to extract chitin influenced the cost production and also gave the low extraction efficacy [18]. As a substitute for chemical and enzymatic processes, lactic acid fermentation combined with microbial deproteinization warrants further investigation because they are eco-friendly and positive procedures. The bacterial strain L. pentosus L7 was found to provide the high acid production, while $B$. thuringiensis SA could produce proteases in a culture medium containing shrimp shells. B. thuringiensis is well known as a bacterium that can produce insecticidal protein and is nonpathogenic to humans.

Therefore, these two bacterial strains were used to extract chitin from shrimp shells. The objective of this work was to investigate a novel process for producing high viscosity chitosan from chitin isolated by two-step purification: the first step using the lactic acid bacterium L. pentosus L7, and the second step using the protease-producing bacterium $B$. thuringiensis SA. Based on our knowledge, no prior study has reported the preparation of chitosan from biologically purified chitin prepared by using a combination of both strains.

\section{Materials and Methods}

2.1. Raw Materials. Shells and heads of marine Pacific white shrimp (Litopenaeus vannamei) were obtained from a seafood wholesaler in Samut Sakhon province, Thailand. Both biowastes were packed into an ice box for transportation and stored frozen at $-20^{\circ} \mathrm{C}$ in the laboratory until used. Before proximate analysis, both shrimp biowastes were washed thoroughly with tap water and dried in a hot-air oven at $102^{\circ} \mathrm{C}$ for 12 hours. For chitin and chitosan flake productions, shrimp shells were homogenized in a blender until small sized pieces $(10-20 \mathrm{~mm})$ were obtained; these were then kept frozen until used.

2.2. Microorganisms. The lactic acid bacterium L. pentosus L7 and proteolytic $B$. thuringiensis SA were obtained from the Department of Microbiology, King Mongkut's University of Technology Thonburi, Thailand. Both strains were kept in a freezer at $-80^{\circ} \mathrm{C}$ for long-term storage and cultured on slants immediately prior to use.

\subsection{Preparation of Shrimp Head Extract Solution (SHES).} Shrimp head extract solution (SHES) was prepared by boiling shrimp heads in deionized water. Briefly, shrimp heads were mixed with deionized water at a ratio of $1: 2(50 \%, \mathrm{w} / \mathrm{v})$ and boiled for 30 minutes. SHES was obtained by filtering the solution through cotton to remove the sediment and then adding deionized water to obtain the initial liquid volume before heat extraction.

2.4. Determination of L. pentosus L7 Growth in Various Culture Media Having SHES as a Major Component. L. pentosus L7 was cultured in de Man, Rogosa, and Sharpe medium (MRS), pH 6.6 (20 g glucose, $10 \mathrm{~g}$ peptone, $5 \mathrm{~g}$ beef extract, $5 \mathrm{~g}$ yeast extract, $5 \mathrm{~g}$ sodium acetate, $2 \mathrm{~g}$ triammonium citrate, $2 \mathrm{~g}$ $\mathrm{K}_{2} \mathrm{HPO}_{4}, 0.1 \mathrm{~g} \mathrm{MgSO}_{4} \cdot 7 \mathrm{H}_{2} \mathrm{O}, 0.05 \mathrm{~g} \mathrm{MnSO}_{4} \cdot 4 \mathrm{H}_{2} \mathrm{O}, 1 \mathrm{~g}$ Tween 80 , and $1,000 \mathrm{~mL}$ distilled water), and incubated at $37^{\circ} \mathrm{C} 24$ hours for use as an inoculum. The growth of L. pentosus L7 in the following culture media: (1) MRS, (2) SHES, (3) SHES plus $2 \%$ glucose, (4) SHES plus $2 \% \mathrm{NaCl}$, (5) SHES plus $2 \%$ glucose and $\mathrm{NaCl}$, and (6) modified MRS medium (using SHES to replace peptone, beef extract, and yeast extract), was determined at $37^{\circ} \mathrm{C}$ using the spread plate technique on MRS agar.

2.5. Determination of B. thuringiensis SA Growth in SHES Compared with Nutrient Broth (NB) and Tryptic Soy Broth (TSB). B. thuringiensis SA was cultured at $37^{\circ} \mathrm{C}$ in nutrient broth (NB), $\mathrm{pH} 7.0$ (5 $\mathrm{g}$ peptone, $3 \mathrm{~g}$ beef extract, $3 \mathrm{~g}$ yeast extract, $5 \mathrm{~g} \mathrm{NaCl}$, and $1,000 \mathrm{~mL}$ distilled water) for 24 hours and used as an inoculum. The growth of $B$. thuringiensis $\mathrm{SA}$ in SHES was determined at $37^{\circ} \mathrm{C}$ using the spread plate technique on nutrient agar (NA) compared with the growth in NB and TSB.

2.6. Chemical Chitin Extraction. A mixture of $500 \mathrm{~g}$ of wet shrimp shells and 2,250 $\mathrm{mL}$ of $4 \% \mathrm{HCl}$ was kept at room temperature for 4 hours to eliminate inorganic components in the shells. The decalcified shrimp shells were then separated and washed several times with tap water. Deproteinization was performed by adding the dried decalcified shrimp shells into $5 \% \mathrm{NaOH}$ at a ratio of $1: 10, \mathrm{w} / \mathrm{v}$. The mixture was shaken in a $90^{\circ} \mathrm{C}$ water bath for 12 hours. Chitin flakes were obtained by washing the solid residue with tap water and drying overnight in an oven at $80^{\circ} \mathrm{C}$.

2.7. Biological Chitin Purification. A 24-hour culture of L. pentosus L7 in SHES plus 2\% glucose was used as a starter in the decalcification step. Shrimp shell flakes $(500 \mathrm{~g})$ were mixed with $500 \mathrm{~mL}$ of starter $(1: 1, \mathrm{w} / \mathrm{v})$ followed by $10 \%$ $(\mathrm{w} / \mathrm{w})$ glucose and $1 \%(\mathrm{w} / \mathrm{w})$ salt in a $1,000 \mathrm{~mL}$ conical flask. Fermentation was performed at $37^{\circ} \mathrm{C}$ for 48 hours; the decalcified shrimp shells were then separated by a sifter. The retentate was washed with tap water and dried in an oven overnight at $80^{\circ} \mathrm{C}$. For deproteinization of the decalcified shrimp shells, $10 \%(\mathrm{v} / \mathrm{v})$ of 24 -hour culture of $B$. thuringiensis $\mathrm{SA}$ in SHES medium was added to a sterilized mineral solution $\left(0.1 \% \mathrm{KH}_{2} \mathrm{PO}_{4}, 0.05 \% \mathrm{MgSO}_{4} \cdot 7 \mathrm{H}_{2} \mathrm{O}\right)$ containing $3 \%(\mathrm{w} / \mathrm{v})$ dried decalcified shrimp shells. The mixture was incubated at $37^{\circ} \mathrm{C}$ with agitation at $200 \mathrm{rpm}$ for 72 hours. The chitin was washed and dried overnight in an oven at $80^{\circ} \mathrm{C}$.

2.8. Chitosan Production. Twenty $\mathrm{mL}$ of $50 \%(\mathrm{w} / \mathrm{v})$ sodium hydroxide solution was added to $1 \mathrm{~g}$ dried decalcified and 
deproteinized chitin. Deacetylation was performed at $121^{\circ} \mathrm{C}$ for 5 hours. Chitosan flakes were obtained by washing the solid residue with tap water until the $\mathrm{pH}$ was neutral and then dried overnight in an oven at $80^{\circ} \mathrm{C}$.

2.9. Analytical Procedures. The $\mathrm{pH}$ of the fermenting liquids was determined using a $\mathrm{pH}$ meter (Metrohm, Riverview, FL, USA). Total titratable acid (TTA) was estimated by titration with $0.1 \mathrm{M} \mathrm{NaOH}$ to neutralize all the total titratable protons. The endpoint was at $\mathrm{pH}$ 8.1. The calculation expresses the titratable acidity in terms of $\mathrm{g} / \mathrm{L}$ of lactic acid. Reducing sugar was determined by the Somogyi-Nelson method [19]. Moisture, protein, and ash contents were considered as the basis for determination of decalcification (DC) and deproteinization (DP) efficiencies. Moisture, fat, and ash contents of samples were determined by AOAC methods [20]. Protein content was analyzed by a modified Biuret method, as described by Gornall et al. [21]. Briefly, $100 \mathrm{mg}$ dried materials were digested with $10 \mathrm{~mL} 0.5 \mathrm{M} \mathrm{NaOH}$ for 4 hours at $40^{\circ} \mathrm{C}$; protein in the alkaline solution mixture was collected by centrifugation and used to estimate the protein concentration. DC and DP were calculated as percentages, according to Rao et al. [14].

For determination of proteolytic activity, the supernatant (crude enzyme) was collected from the culture by centrifugation at $10,000 \times \mathrm{g}$ at $4^{\circ} \mathrm{C}$ for 10 minutes. One hundred twenty $\mu \mathrm{L}$ of a diluted enzyme solution was added to $480 \mu \mathrm{L}$ of azocasein $(0.5 \%$ in $50 \mathrm{mM}$ Tris buffer, $\mathrm{pH} 8.0$, containing $5 \mathrm{mM} \mathrm{MgCl}_{2}$ ) and the mixture was incubated at $37^{\circ} \mathrm{C}$ for 1 hour. The reaction was stopped by adding $600 \mu \mathrm{L}$ of $10 \%$ trichloroacetic acid; this was mixed and allowed to sit for 30 minutes at $4^{\circ} \mathrm{C}$. The liquid was separated from the precipitate by centrifugation at $10,000 \times \mathrm{g}$ at $4^{\circ} \mathrm{C}$ for 15 minutes. Four hundred $\mu \mathrm{L}$ of $1.8 \mathrm{~N} \mathrm{NaOH}$ was added to $800 \mu \mathrm{L}$ of the reaction liquid, mixed, and measured for absorbance at $420 \mathrm{~nm}\left(A_{420}\right)$ using a microplate reader (Varian Cary 50 MPR; Varian, Medical Systems, Palo Alto, CA, USA). One unit of enzyme activity was defined as the amount which yielded an increase in $A_{420}$ of 0.01 in 60 minutes at $37^{\circ} \mathrm{C}$.

The degree of acetylation of chitin and chitosan samples was determined by UV-Vis spectroscopy, as described by $\mathrm{Wu}$ and Zivanovic [22].

For color analysis, $L^{*}, a^{*}$, and $b^{*}$ values were measured by a Hunter Lab UltraScan XE Colorimeter (HunterLab, Reston, VA, USA) using the CIELAB color system, where $L^{*}$ indicates lightness on a scale ranging from 0 (black) to 100 (white), while positive and negative values of $a^{*}$ represent red and green, and positive and negative values of $b^{*}$ represent yellow and blue, respectively. The whiteness index (WI) was calculated based on the following [3]:

$$
\mathrm{WI}=100-\left[\left(100-L^{*}\right)^{2}+a^{* 2}+b^{* 2}\right]^{1 / 2} .
$$

Viscosities of chitin and chitosan samples were determined using a rheometer (Physica MCR 150; Anton Paar, Ashland, VA, USA) according to a modification of the Bajaj method [23]. Chitin samples were dipped into 50\% ethanol for 30 minutes at $45^{\circ} \mathrm{C}$ to remove fat content. The chitin was then crushed into powder. $\mathrm{N}, \mathrm{N}$-dimethylacetamide (DMA)
TABLE 1: Chemical properties of shrimp shells and heads.

\begin{tabular}{lcc}
\hline $\begin{array}{l}\text { Component } \\
(\%, w / w)\end{array}$ & $\begin{array}{c}\text { Shrimp shells } \\
\text { (abdominal) }\end{array}$ & Shrimp heads \\
\hline $\begin{array}{l}\text { Moisture } \\
\text { Crude } \\
\text { protein }\end{array}$ & $80.0 \pm 0.3$ & $86.1 \pm 2.2$ \\
Lipid & $25.9 \pm 2.0$ & $40.7 \pm 2.7$ \\
Ash & $2.4 \pm 1.0$ & $13.9 \pm 1.1$ \\
Chitin $^{\text {a }}$ & $27.9 \pm 0.9$ & $22.2 \pm 0.6$ \\
\hline
\end{tabular}

${ }^{\mathrm{a}}$ by calculation.

TABlE 2: Chemical properties of shrimp head residue after heat extraction.

\begin{tabular}{lc}
\hline Component & Residue after heat extraction $(\%, w / w)$ \\
\hline Crude protein & $38.0 \pm 3.7$ \\
Lipid & $5.0 \pm 0.3$ \\
Ash & $27.5 \pm 1.9$ \\
\hline
\end{tabular}

(99.5\%, anhydrous, Unilab; Ajax Finechem, NSW, Australia) containing $5 \%$ lithium chloride $(\mathrm{LiCl})(98.0 \%$, anhydrous; LOBA Chemie, Mumbai, India) was used to prepare $0.1 \%$ $(\mathrm{w} / \mathrm{v})$ chitin solution. The mixture was stirred for 120 hours at room temperature. Chitosan solutions $(1 \%, \mathrm{w} / \mathrm{v})$ were obtained by dissolving chitosan powder in diluted acetic acid $(1 \%, v / v)$. Each mixture was stirred for 24 hours at $55^{\circ} \mathrm{C}$. A cone and plate geometry with a cone angle of $2.0^{\circ}$ and radius of $24.975 \mathrm{~mm}$ was used for the measurements, and the gap size was $0.49 \mu$. The shear rates ranged from 0.1 to $100 \mathrm{~s}^{-1}$. The experiments were conducted at $20^{\circ} \mathrm{C}$. High, medium, and low viscosity chitosan represented viscosities of $\geq 400,200-400$, and $\leq 200 \mathrm{mPa} \cdot \mathrm{s}$, respectively [23].

2.10. Data Analysis. All experiments were run in triplicate. Experimental data were expressed as mean \pm s.d. $(n=6)$.

\section{Results}

3.1. Chemical Compositions of Raw Materials. Table 1 shows the composition of shrimp shells (abdominal part) and shrimp heads. The shrimp abdominal shells had less protein and lipid than shrimp heads; therefore, the abdominal part was the preferred raw material for chitin and chitosan preparations. The cost of the culture media for L. pentosus L7 and B. thuringiensis SA used in the process was a high investment. Shrimp heads are a readily available biowaste material, and SHES obtained by heat extraction process is cheap and easy to prepare. The SHES contained crude protein content of $1.0 \pm 0.1 \%$, which could well support the growth of these bacteria. The residue after extraction still had some nutritional value (Table 2), which could be used for other applications such as animal feed production.

3.2. Microorganisms. Lactobacillus pentosus L7 was isolated from the Thai traditional fermented sausage, known as "Nham." L. pentosus L7 showed high acid production efficacy 


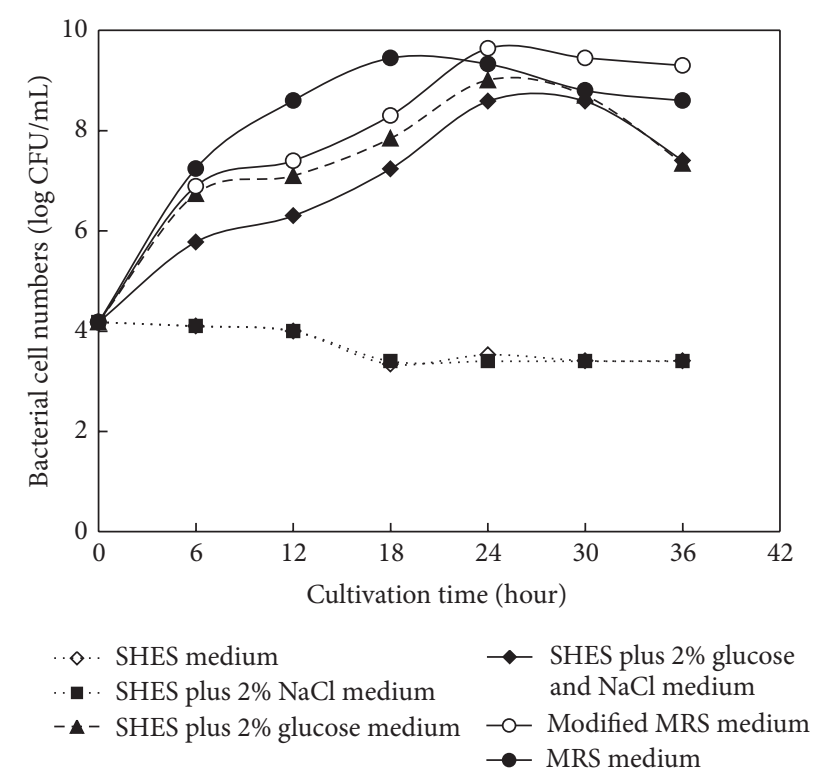

Figure 1: Growth of L. pentosus L7 in six different culture media.

when glucose was supplemented as a carbon source for lactic acid production. A protease-producing bacterium, $B$. thuringiensis SA, was screened and isolated from coastline in Bangkhuntien district area, Bangkok, by using the doublelayer agar technique. B. thuringiensis SA showed strong gelatinase, caseinase, and collagenase activities. Using the combination of both strains to decalcify and deproteinize shrimp shells, purified chitin with high quality could be obtained.

3.3. Growth of L. pentosus $L 7$ and B. thuringiensis $S A$ in Culture Media Having SHES as a Major Component. A 24hour culture of L. pentosus L7 (0.1\%) in MRS broth was inoculated into MRS; SHES; SHES plus $2 \%$ glucose; SHES plus $2 \% \mathrm{NaCl}$; SHES plus $2 \%$ glucose and $\mathrm{NaCl}$; and modified MRS medium. The growth curves of $L$. pentosus L7 in these media were performed using the spread plate technique on MRS agar (Figure 1). The SHES could not support the growth of L. pentosus L7 unless a carbon source such as glucose was supplemented. The modified MRS medium which used SHES to replace peptone, beef extract, and yeast extract could satisfactorily promote the growth of $L$. pentosus $\mathrm{L} 7$ similar to the MRS medium. L. pentosus L7 cell numbers reached $9.2 \pm 0.2 \log \mathrm{CFU} / \mathrm{mL}$ after 24 -hour cultivation. SHES plus $2 \%$ glucose could also promote the growth of $L$. pentosus L7; cell numbers reached $8.5 \pm 0.2 \log \mathrm{CFU} / \mathrm{mL}$ after 24 hour cultivation. SHES plus $2 \%$ glucose could save on the cost of inoculum medium; therefore, SHES plus $2 \%$ glucose medium was selected as the cultivation medium to prepare the inoculum for lactic acid fermentation of shrimp shells. When a 24 -hour culture of $0.1 \%$ B. thuringiensis SA in NB was inoculated into SHES, NB, and TSB, the three media gave similar growth support for the bacteria. The cell numbers of
TABLE 3: Residual crude protein and ash content in decalcified shrimp shells and raw chitin flakes during purification by a two-step biological process.

\begin{tabular}{lcc}
\hline Biological process & $\begin{array}{c}\text { Crude protein } \\
(\%, w / w)\end{array}$ & $\begin{array}{c}\text { Ash content } \\
(\%, w / w)\end{array}$ \\
\hline \multicolumn{3}{c}{ First step: $L$. pentosus L7 fermentation } \\
48 hours & $26.3 \pm 1.2$ & $3.8 \pm 0.4$ \\
\hline \multicolumn{1}{c}{ Second step: deproteinization with B. } & thuringiensis SA \\
24 hours & $16.4 \pm 2.5$ & $1.5 \pm 0.4$ \\
48 hours & $8.0 \pm 1.2$ & $1.5 \pm 0.4$ \\
72 hours & $3.8 \pm 1.3$ & $1.7 \pm 0.4$ \\
\hline
\end{tabular}

B. thuringiensis SA reached $8.6 \pm 0.2 \log \mathrm{CFU} / \mathrm{mL}$ after 24 hour cultivation indicating that SHES would be suitable for use as the culture medium for $B$. thuringiensis SA.

3.4. Two-Step Biological Chitin Purification of Shrimp Shells. Removal of protein and calcium from shrimp shells is critical step in chitin purification. Lactic acid fermentation was selected as the first process in a two-step biological chitin extraction. The fermentation time for calcium removal could be decreased by increasing the inoculum size, but a high inoculum level had a significant effect on the production costs. As noted in the previous section, L. pentosus L7 could grow well in SHES plus $2 \%$ glucose. Changes in the amount of reducing sugar, lactic acid, number of $L$. pentosus L7 cells, and $\mathrm{pH}$ of the fermenting liquid were determined (Figure 2). The initial $\mathrm{pH}$ of $7.0 \pm 0.1$ fell to $3.9 \pm 0.1$ after 48 hours and continued to decrease slightly upon further incubation. The acidity was the highest after 48 hours and then remained at that level. The reducing sugar in the fermenting liquid remained at only $4.0 \pm 0.1 \mathrm{~g} / \mathrm{L}$ after 72 hours. In the first 24 hours, the number of L. pentosus L7 cells increased to $11.0 \pm 0.2 \log \mathrm{CFU} / \mathrm{mL}$ indicating significant growth. Over the first 24 hours, the ash content in shrimp shells sharply decreased from $27.9 \pm 0.9 \%$ to $3.8 \pm 0.4 \%$ (Table 3 ). The results suggested that the fermentation process ended after 48 hours as indicated by constant $\mathrm{pH}$ and lactic acid concentration (Figure 2). At the end of fermentation, the decalcified shrimp shells had crude protein and ash contents of $23.2 \pm 2.5 \%$ and $1.4 \pm 0.4 \%$, respectively (Table 3 ). The decalcified shrimp shells were further processed by a deproteinization step via the proteolytic activity of $B$. thuringiensis SA. The proteolytic activity and soluble protein in the extraction liquid were examined (Figure 3). The highest proteolytic activity, $290.1 \pm$ $15.8 \mathrm{unit} / \mathrm{mL}$, was detected after 48 hours and the highest amount of soluble protein in the extraction liquid was found after 72 hours; this indicated that the deproteinization could be considered finished after 72 hours. At the end of the process, decalcification and deproteinization efficiencies of the two-step biological extraction were $98.1 \pm 0.3 \%$ and $96.8 \pm 0.7 \%$, respectively (Figure 4 ).

3.5. Properties of Chitin Flakes Obtained from Chemical and Two-Step Biological Processes. The composition of the shrimp 


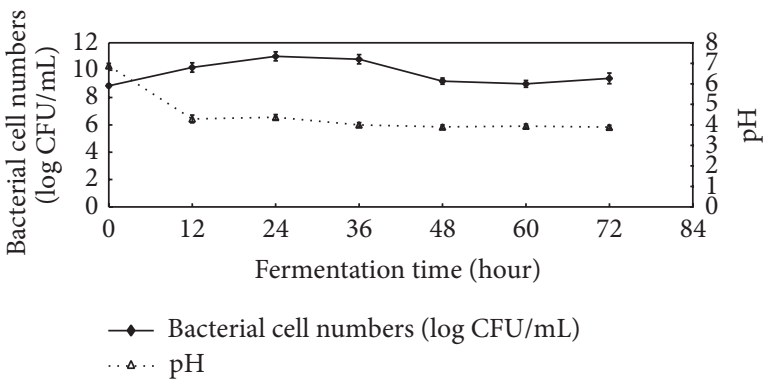

(a)

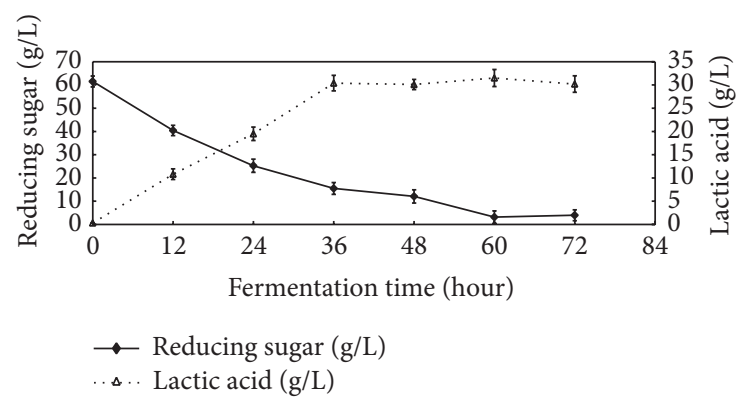

(b)

Figure 2: Changes in $\mathrm{pH}$, lactic acid, cell numbers of L. pentosus L7, and reducing sugar in the fermenting liquid during decalcification of shrimp shells by L. pentosus L7.

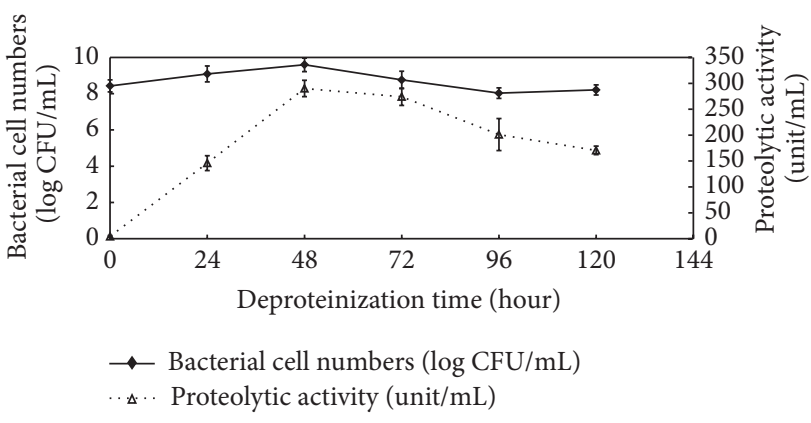

(a)

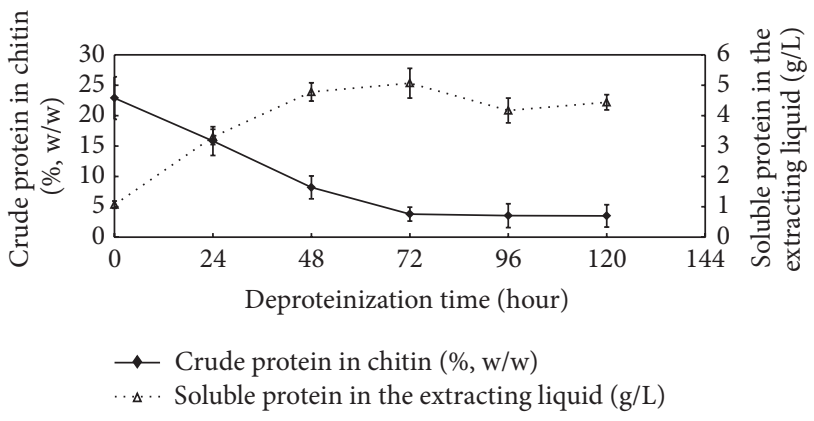

(b)

FIGURE 3: Deproteinization of decalcified shrimp shells by B. thuringiensis SA.

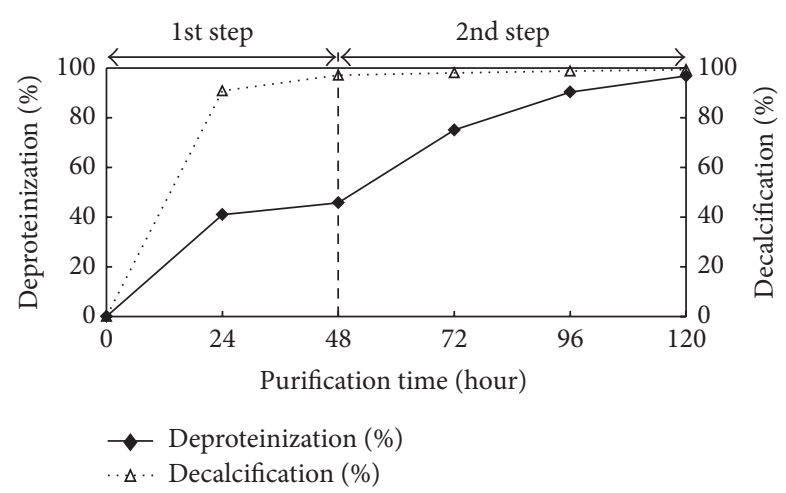

Figure 4: Deproteinization and decalcification efficacies from shrimp shell waste during the first step fermentation with L. pentosus L7 and the second step deproteination with B. thuringiensis SA.

shells after extraction by chemical or two-step biological treatments is shown in Table 4. The results revealed that the chemical treatment for chitin production was more effective in deproteinization and decalcification than the biological process. However, protein and ash contents are not the only parameters to be considered for chitin quality. Molecular weight distribution, degree of acetylation (DA), grade of polymerization, and viscosity of chitin are also considered important parameters of chitin quality. Among these, viscosity and DA are commonly used as quality indicators [6].
In this study, viscosity measurements were performed to determine the rheological properties of extracted chitin. The viscosity of biologically purified chitin was $110 \pm 15.1 \mathrm{mPa} \cdot \mathrm{s}$, whereas the viscosity of chemically processed chitin was $82 \pm 13.6 \mathrm{mPa} \cdot \mathrm{s}$ (Table 4). In terms of color analysis, the chemically processed chitin had a lighter color than that from the biological process (Table 4). However, both showed a white property, leading to greater consumer preference and acceptability of the product. The biological process could preserve the structure of shrimp chitin better than the chemical process by retaining higher DA and viscosity.

\subsection{Properties of Chitosan Flakes Obtained from Chitin} Extracted by Chemical and Two-Step Biological Processes. Chitin obtained from shrimp shells after extraction by chemical and two-step biological processes was incubated with $50 \% \mathrm{NaOH}\left(121^{\circ} \mathrm{C}\right.$ for 5 hours) for deacetylation to chitosan. Chitosan is a polymer of $\beta$-(1-4)-D-glucosamine units, which can be obtained by deacetylation of chitin, a polymer of $\beta$-(1-4)- $N$-acetyl-D-glucosamine (NAG) units. Under the selected deacetylation condition, the degree of deacetylation of chitosan was higher than 70\% (Table 5), leading to solubility in $1 \%$ acetic acid. The chitosan derived from the biologically purified chitin was more viscous than the chitosan manufactured by the chemical process (323 \pm $15.6 \mathrm{mPa} \cdot \mathrm{s})$, in which viscosity of $1,007 \pm 14.7 \mathrm{mPa} \cdot \mathrm{s}$ was obtained from chitosan prepared from biologically purified 
TABLE 4: Properties of chitin flakes obtained from chemical and twostep biological processes.

\begin{tabular}{|c|c|c|}
\hline \multirow[b]{2}{*}{ Properties } & \multicolumn{2}{|c|}{ Shrimp chitin flake products } \\
\hline & $\begin{array}{l}\text { Chemical } \\
\text { process }\end{array}$ & $\begin{array}{c}\text { Biological } \\
\text { process }\end{array}$ \\
\hline $\mathrm{pH}$ & 7 & 7 \\
\hline Appearance & White & $\begin{array}{c}\text { White and light } \\
\text { yellow }\end{array}$ \\
\hline Crude protein $(\%, \mathrm{w} / \mathrm{w})$ & $0.3 \pm 0.1$ & $3.8 \pm 1.3$ \\
\hline $\operatorname{Ash}(\%, w / w)$ & $0.6 \pm 0.1$ & $1.7 \pm 0.4$ \\
\hline Deproteination efficacy (\%) & $99.7 \pm 0.1$ & $96.8 \pm 0.7$ \\
\hline Decalcification efficacy (\%) & $99.0 \pm 0.1$ & $98.1 \pm 0.3$ \\
\hline \multicolumn{3}{|l|}{ Color properties } \\
\hline$L^{*}$ & $87.3 \pm 1.6$ & $84.7 \pm 1.2$ \\
\hline$a^{*}$ & $0.3 \pm 0.1$ & $0.7 \pm 0.2$ \\
\hline$b^{*}$ & $7.0 \pm 0.1$ & $7.2 \pm 1.4$ \\
\hline $\mathrm{WI}^{\mathrm{a}}$ & 85.5 & 83.1 \\
\hline Degree of acetylation (\%) & $96.5 \pm 0.3$ & $98.2 \pm 0.5$ \\
\hline $\operatorname{Viscosity}^{\mathrm{b}}(\mathrm{mPa} \cdot \mathrm{s})$ & $82.0 \pm 13.6$ & $110.0 \pm 15.1$ \\
\hline Yield (\%) & $20.0 \pm 0.5$ & $25.4 \pm 1.2$ \\
\hline
\end{tabular}

${ }^{a}$ whiteness index, by calculation.

${ }^{b}$ viscosity determined at shear rate of $20 \mathrm{~s}^{-1}\left(25^{\circ} \mathrm{C}\right)$.

chitin. In terms of color analysis, chitosan prepared from biologically purified chitin had a lighter color than chitosan prepared from chemically processed chitin (Table 5). Chitosan prepared from biologically purified chitin had crude protein and calcium contents of $0.4 \pm 0.3 \%$ and $1.6 \pm 0.6 \%$, respectively. The degree of deacetylation was $83.2 \pm 1.5 \%$.

\section{Discussion}

The applications of microorganisms, proteolytic enzymes, and shrimp shell fermentation for deproteinization or decalcification of seafood industry wastes are a current research trend in the conversion of biowastes into valueadded biomass. The biological process is an environmentally friendly alternative for preparation of chitin. In this study, two-step biological chitin production from shrimp shells, using lactic acid fermentation for decalcification followed by bacterial proteolysis for deproteinization, was performed. The abdominal part of the shrimp shell was selected as a raw material for chitin preparation, since it contained low protein and fat (Table 1).

The high cost of media for cultivating lactic acid bacteria and $B$. thuringiensis could be overcome by protein extraction of shrimp head waste (SHES). The price of synthetic culture medium (broth) for lactobacilli is about 400 baht per L; whereas the cost for preparation of culture medium made from SHES plus 2\% glucose is about 9 baht per L. Also, the solid residue after SHES preparation still had some nutritional value and can be used as an animal feed supplement.

A fast removal of proteins from shrimp abdominal shells is necessary to avoid spoilage and the development of a bad smell. Shrimp shell fermentation by lactic acid bacteria for
TABLE 5: Properties of chitosan flakes obtained from deacetylation of chitin extracted by chemical and two-step biological processes.

\begin{tabular}{|c|c|c|}
\hline \multirow[b]{2}{*}{ Properties } & \multicolumn{2}{|c|}{ Shrimp chitosan flake products } \\
\hline & $\begin{array}{l}\text { Deacetylation of } \\
\text { chemically } \\
\text { processed chitin }\end{array}$ & $\begin{array}{c}\text { Deacetylation of } \\
\text { biologically } \\
\text { purified chitin }\end{array}$ \\
\hline $\mathrm{pH}$ & 7 & 7 \\
\hline Appearance & White & White \\
\hline Crude protein $(\%, w / w)$ & $0.3 \pm 0.1$ & $0.4 \pm 0.3$ \\
\hline $\operatorname{Ash}(\%, w / w)$ & $0.3 \pm 0.1$ & $1.6 \pm 0.6$ \\
\hline \multicolumn{3}{|l|}{ Color properties } \\
\hline$L^{*}$ & $73.1 \pm 2.0$ & $77.3 \pm 1.4$ \\
\hline$a^{*}$ & $0.5 \pm 0.1$ & $0.7 \pm 0.2$ \\
\hline$b^{*}$ & $7.0 \pm 0.3$ & $6.4 \pm 0.6$ \\
\hline $\mathrm{WI}^{\mathrm{a}}$ & 72.1 & 76.4 \\
\hline Degree of deacetylation (\%) & $82.2 \pm 1.2$ & $83.2 \pm 1.5$ \\
\hline Viscosity $^{\mathrm{b}}(\mathrm{mPa} \cdot \mathrm{s})$ & $323.0 \pm 15.6$ & $1,007 \pm 14.7$ \\
\hline
\end{tabular}

${ }^{\mathrm{a}}$ whiteness index, by calculation.

${ }^{b}$ viscosity was determined at shear rate of $50 \mathrm{~s}^{-1}\left(20^{\circ} \mathrm{C}\right)$.

decalcification and deproteinization would be an alternative approach for inhibition of spoilage microorganisms. By fermentation of shrimp shells with lactobacilli, a decalcification efficiency of up to $86 \%$ has been reported [6, 14, 16, 24-27]. In the present study, decalcification efficacy with $L$. pentosus L7 reached $97 \%$ but required $10 \%(\mathrm{w} / \mathrm{w})$ glucose. This is in accordance with previous reports $[6,24,27]$ : for example, $15 \%(\mathrm{w} / \mathrm{w})$ was the optimum glucose concentration for Pediococcus acidilactici fermentation to remove calcium from shrimp shells [27], while $2.5 \mathrm{~g}$ crab shells were decalcified with $50 \mathrm{~mL}$ of $10 \%$ glucose (solid to liquid ratio of $1: 20$ ) [24]; and for decalcification of P. monodon shells, $0.54 \mathrm{~g}$ glucose per $\mathrm{g}$ of dried shells was added to decrease $\mathrm{pH}$ to 4.6 [6]. The decrease of residual proteins in shrimp shells after fermentation indicated that deproteinization of the shrimp shells occurred spontaneously, together with decalcification by the proteolytic activity of $L$. pentosus L7 or by the in situ proteases in the biowaste [6]. The presence of the lactic acid bacterium L. pentosus L7 $(9.0 \pm 0.2 \log \mathrm{CFU} / \mathrm{mL})$ in the protein and calcium rich liquor portion indicates that it could be used as a food supplement for humans, animals, or microorganisms [28].

In the deproteinization step, $B$. thuringiensis SA produced high protease activity $(290.1 \pm 15.8$ unit/mL) during deproteinization of decalcified shrimp shells. The liquid fraction should be collected and concentrated to obtain the crude protease. B. thuringiensis SA was found to produce parasporal crystal proteins during the sporulation stage; the crystal protein might be recovered from the extracting liquid after deproteinization of decalcified shrimp shells.

Quality criteria of chitosan are viscosity, molecular weight, or distribution of molar masses. The viscosity of chitosan is strongly dependent on the viscosity of the "preproduct" chitin; the biological processes have been reported to be an effective way to obtain a high quality of chitin $[6,7,17-19]$. 


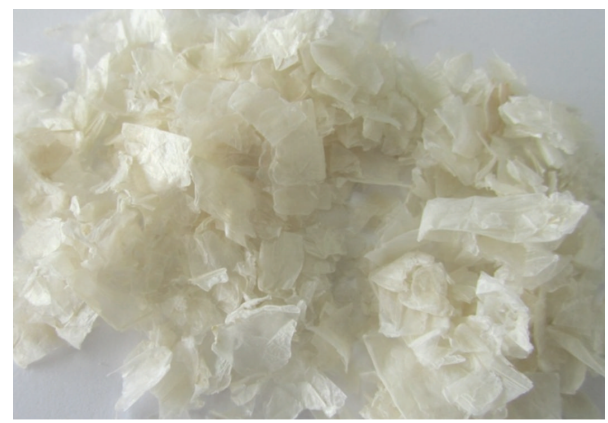

FIGURE 5: Chitosan flakes obtained from biologically purified chitin.

The chitosan obtained from biologically purified chitin had a high viscosity compared with chitosan prepared from chemically processed chitin (the same lot of shrimp waste in the present study, Table 5). Commercial chitosan purchased from a supplier in Samut Sakhon province, Thailand, had a viscosity of $331 \mathrm{mPa} \cdot \mathrm{s}$. Bajaj et al. [23] reported that commercial chitosan with high viscosity had $442.4 \mathrm{mPa} \cdot \mathrm{s}$, while the medium and low viscous grades had much lower viscosities; this indicated that the quality of the chitosan used in the present study was good. Although the highest chitosan viscosity was reported by Bajaj et al. [23], a chemical process was used to prepare chitin, together with an $\mathrm{N}_{2}$ atmosphere for deacetylation.

The production of chitosan from chitin isolated by a twostep biological purification process for decalcification and deproteinization is not commercially used, but the process has good potential to create biologically purified chitin with a high grade of purity and provides a high viscosity chitosan after deacetylation (Figure 5). High viscosity chitosan has various applications, for example, as an emulsifying agent, or dietary ingredient, and for metal reduction, scaffolds (tissue engineering), enzyme immobilization, and drug delivery [28]. The disadvantages of a two-step biological process are overall longer purification time (5 days) and higher costs due to the requirement of sterilize process and a carbon source in deproteinization and decalcification steps. However, the wastes from the biological processing are not harmful to humans or the environment, and useful by-products such as protein hydrolysate, calcium lactate, astaxanthin, crude protease, and parasporal crystal proteins during purification could be obtained from the methods used in the present study, whereas chemical process creates toxic waste and causes some depolymerization of the chitin, which influences its molecular weight and viscosity, leading to lower viscosity chitosan after deacetylation.

\section{Conclusions}

Chitin purification procedures play an important role in obtaining a high viscosity chitosan after deacetylation. Compared with the chitosan product made from chemically processed chitin, high viscosity chitosan can be successfully prepared by a biological process.

\section{Conflict of Interests}

The authors declare that there is no conflict of interests regarding the publication of this paper.

\section{References}

[1] J. V. Ornum, "Shrimp waste-must it be wasted?" Infofish International, vol. 6, p. 48, 1992.

[2] D. Knorr, "Recovery and utilization of chitin and chitosan in food processing waste management," Food Technology, vol. 26, pp. 114-122, 1991.

[3] M. S. Heu, J. S. Kim, and F. Shahidi, "Components and nutritional quality of shrimp processing by-products," Food Chemistry, vol. 82, no. 2, pp. 235-242, 2003.

[4] W. L. Teng, E. Khor, T. K. Tan, L. Y. Lim, and S. C. Tan, "Concurrent production of chitin from shrimp shells and fungi," Carbohydrate Research, vol. 332, no. 3, pp. 305-316, 2001.

[5] N. M. Sachindra, N. Bhaskar, and N. S. Mahendrakar, "Carotenoids in different body components of Indian shrimps," Journal of the Science of Food and Agriculture, vol. 85, no. 1, pp. 167-172, 2005.

[6] Y. Xu, C. Gallert, and J. Winter, "Chitin purification from shrimp wastes by microbial deproteination and decalcification," Applied Microbiology and Biotechnology, vol. 79, no. 4, pp. 687697, 2008.

[7] V. Venugopal, Marine Products for Healthcare: Functional and Bioactive Nutraceutical Compounds From the Ocean, CRC Press Taylor \& Francis Group, Boca Raton, Fla, USA, 2009.

[8] K. L. B. Chang and G. Tsai, "Response surface optimization and kinetics of isolating chitin from pink shrimp (Solenocera melantho) shell waste," Journal of Agricultural and Food Chemistry, vol. 45, no. 5, pp. 1900-1904, 1997.

[9] J. S. Mojarrad, M. Nemati, H. Valizadeh, M. Ansarin, and S. Bourbour, "Preparation of glucosamine from exoskeleton of shrimp and predicting production yield by response surface methodology," Journal of Agricultural and Food Chemistry, vol. 55, no. 6, pp. 2246-2250, 2007.

[10] P. A. Felse and T. Panda, "Studies on applications of chitin and its derivatives," Bioprocess Engineering, vol. 20, no. 6, pp. 505$512,1999$.

[11] F. Khoushab and M. Yamabhai, "Chitin research revisited," Marine Drugs, vol. 8, no. 7, pp. 1988-2012, 2010.

[12] G. T. Kjartansson, S. Zivanovic, K. Kristbergsson, and J. Weiss, "Sonication-assisted extraction of chitin from North Atlantic shrimps (Pandalus borealis)," Journal of Agricultural and Food Chemistry, vol. 54, no. 16, pp. 5894-5902, 2006.

[13] A. Percot, C. Viton, and A. Domard, "Optimization of chitin extraction from shrimp shells," Biomacromolecules, vol. 4, no. 1, pp. 12-18, 2003.

[14] M. S. Rao, J. Muñoz, and W. F. Stevens, "Critical factors in chitin production by fermentation of shrimp biowaste," Applied Microbiology and Biotechnology, vol. 54, no. 6, pp. 808-813, 2000.

[15] P. Kandra, M. M. Challa, and H. K. P. Jyothi, "Efficient use of shrimp waste: present and future trends," Applied Microbiology and Biotechnology, vol. 93, no. 1, pp. 17-29, 2012.

[16] J. Bautista, M. Jover, J. F. Gutierrez et al., "Preparation of crayfish chitin by in situ lactic acid production," Process Biochemistry, vol. 37, no. 3, pp. 229-234, 2001. 
[17] K. T. Oh, Y. J. Kim, V. N. Nguyen, W. Jung, and R. Park, “Demineralization of crab shell waste by Pseudomonas aeruginosa F722," Process Biochemistry, vol. 42, no. 7, pp. 1069-1074, 2007.

[18] G. H. Jo, W. J. Jung, J. H. Kuk, K. T. Oh, Y. J. Kim, and R. D. Park, "Screening of protease-producing Serratia marcescens FS-3 and its application to deproteinization of crab shell waste for chitin extraction," Carbohydrate Polymers, vol. 74, no. 3, pp. 504-508, 2008.

[19] N. J. Nelson, "A photometric adaptation of the Somogyi method for the determination of glucose," The Journal of Biological Chemistry, vol. 153, pp. 375-380, 1944.

[20] Association of Official Analytical Chemists, Official Methods of Analysis of AOAC International, Association of Official Analytical Chemists, Arlington, Va, USA, 16th edition, 1995.

[21] A. G. Gornall, C. J. Bardawill, and M. M. David, "Determination of serum proteins by means of the Biuret reaction," Journal of Biological Chemistry, vol. 177, no. 2, pp. 751-766, 1949.

[22] T. Wu and S. Zivanovic, "Determination of the degree of acetylation (DA) of chitin and chitosan by an improved first derivative UV method," Carbohydrate Polymers, vol. 73, no. 2, pp. 248-253, 2008.

[23] M. Bajaj, J. Winter, and C. Gallert, "Effect of deproteination and deacetylation conditions on viscosity of chitin and chitosan extracted from Crangon crangon shrimp waste," Biochemical Engineering Journal, vol. 56, no. 1-2, pp. 51-62, 2011.

[24] W. J. Jung, G. H. Jo, J. H. Kuk, Y. J. Kim, K. T. Oh, and R. D. Park, "Production of chitin from red crab shell waste by successive fermentation with Lactobacillus paracasei KCTC3074 and Serratia marcescens FS-3," Carbohydrate Polymers, vol. 68, no. 4, pp. 746-750, 2007.

[25] L. A. Cira, S. Huerta, G. M. Hall, and K. Shirai, "Pilot scale lactic acid fermentation of shrimp wastes for chitin recovery," Process Biochemistry, vol. 37, no. 12, pp. 1359-1366, 2002.

[26] L. Adour, W. Arbia, A. Amrane, and N. Mameri, "Combined use of waste materials-recovery of chitin from shrimp shells by lactic acid fermentation supplemented with date juice waste or glucose," Journal of Chemical Technology and Biotechnology, vol. 83, no. 12, pp. 1664-1669, 2008.

[27] N. Bhaskar, P. V. Suresh, P. Z. Sakhare, and N. M. Sachindra, "Shrimp biowaste fermentation with Pediococcus acidolactici CFR2182: optimization of fermentation conditions by response surface methodology and effect of optimized conditions on deproteination/demineralization and carotenoid recovery," Enzyme and Microbial Technology, vol. 40, no. 5, pp. 1427-1434, 2007.

[28] I. Aranaz, M. Mengíbar, R. Harris et al., "Functional characterization of chitin and chitosan," Current Chemical Biology, vol. 3, no. 2, pp. 203-230, 2009. 

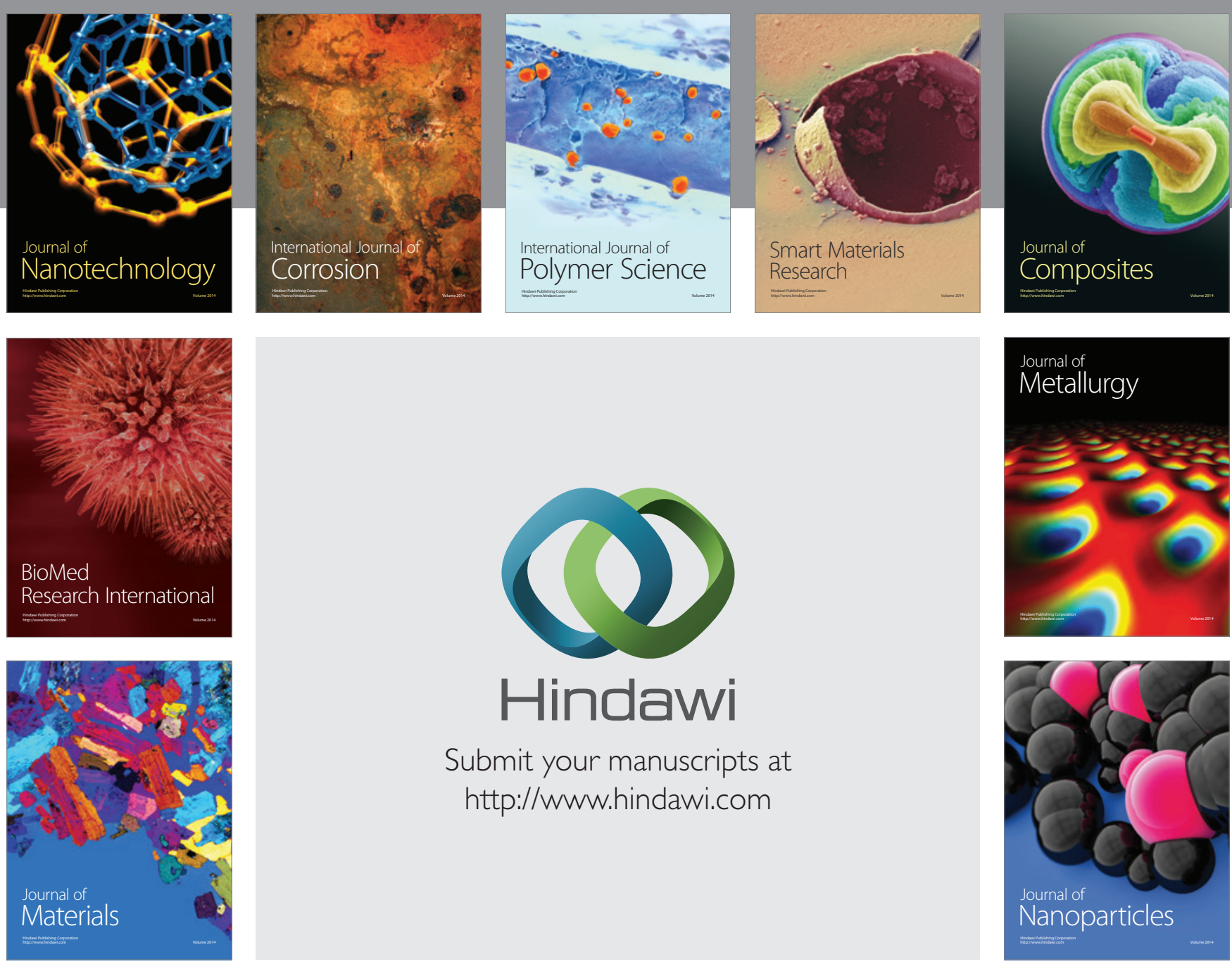

Submit your manuscripts at http://www.hindawi.com
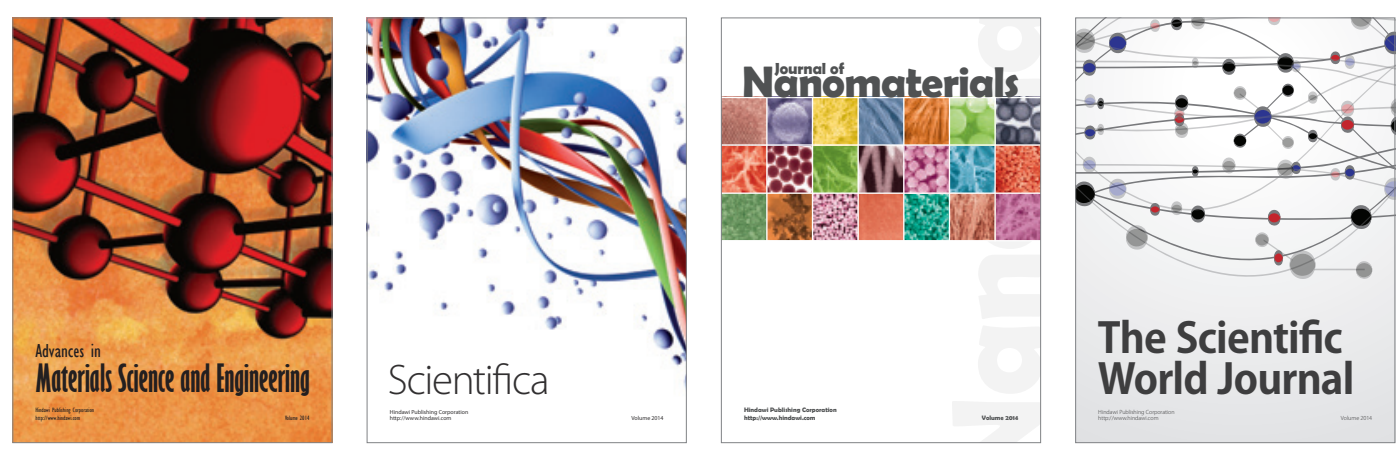

\section{The Scientific World Journal}
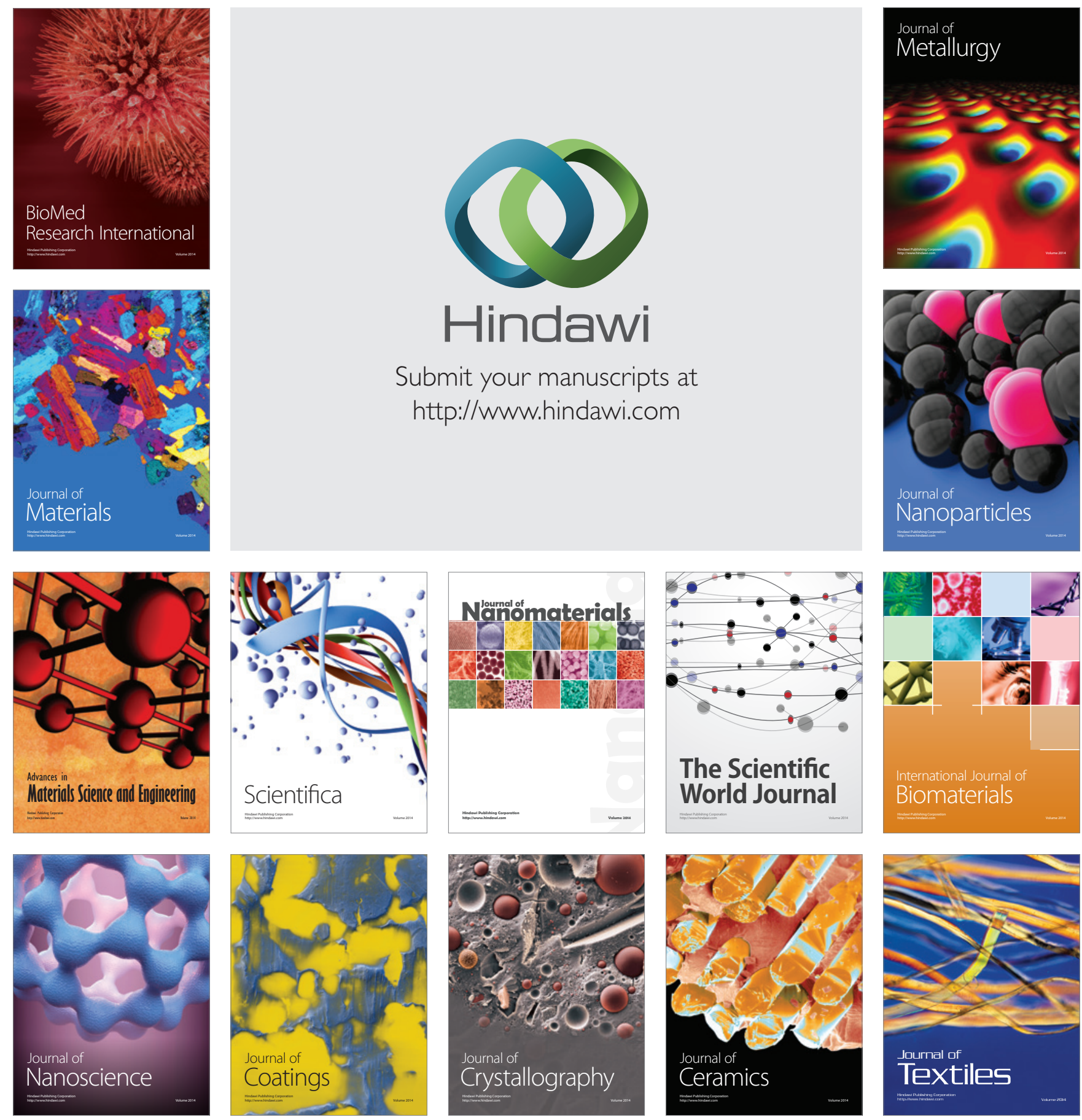